University of Chicago Law School

Chicago Unbound

\title{
Should Indirect Purchasers Have Standing to Sue under the Antitrust Laws? An Economic Analysis of the Rule of Illinois Brick
}

Richard A. Posner

William M. Landes

Follow this and additional works at: https://chicagounbound.uchicago.edu/journal_articles

Part of the Law Commons

\section{Recommended Citation}

Richard A. Posner \& William M. Landes, "Should Indirect Purchasers Have Standing to Sue under the Antitrust Laws? An Economic Analysis of the Rule of Illinois Brick," 46 University of Chicago Law Review 602 (1979).

This Article is brought to you for free and open access by the Faculty Scholarship at Chicago Unbound. It has been accepted for inclusion in Journal Articles by an authorized administrator of Chicago Unbound. For more information, please contact unbound@law.uchicago.edu. 


\title{
Should Indirect Purchasers Have Standing To Sue Under the Antitrust Laws? An Economic Analysis of the Rule of Illinois Brick*
}

\author{
William M. Landes $\dagger$ \\ Richard A. Posnert†
}

Many producers do not sell directly to their ultimate consumers. The producer of a consumer good may, for example, sell it to a wholesaler who will resell it to a retailer who in turn will resell it to the ultimate consumer, and even if there is no wholesale stage of distribution, the ultimate consumer will ordinarily be the direct purchaser from a retailer and only an "indirect purchaser" from the producer. The product" may be used as an input into a final consumer good-for example, the flour sold to a baker who makes it into bread that is sold to the consumer. The product may not even appear physically in the final good-for example, the oven used by the baker in making the bread. In these cases as well, the ultimate consumer is only an indirect purchaser of the flour or the oven, the cost of which will be reflected in the price of the bread.

In Illinois Brick Co. v. Illinois, ${ }^{1}$ the Sureme Court held that indirect purchasers do not have standing to sue for violations of the antitrust laws under section 4 of the Clayton Act, ${ }^{2}$ which authorizes private treble-damage suits by individuals or firms injured in their business or property by a violation of those laws. To understand this decision, one must go back to Hanover Shoe Co. $v$. United Shoe Machinery Corp. ${ }^{3}$ a suit by a shoe manufacturer against a manufacturer of shoe machinery who had earlier been found to have monopolized the shoe machinery industry in violation of section 2 of the Sherman Act. ${ }^{4}$ The defendant argued that it should be allowed to show that its customer had not in fact been injured by the antitrust violation because the customer had passed on the costs of the viola-

* This article is based on testimony the authors gave before the Subcommittee on Antitrust and Monopoly of the Senate Committee on the Judiciary on March 14, 1979. Although we were asked to testify by the Business Roundtable, the views expressed in our testimony and contained in this article are our own and are not necessarily shared by the Roundtable.

$\dagger$ Professor of Economics, The University of Chicago Law School.

t† Lee and Brena Freeman Professor of Law, The University of Chicago.

1431 U.S. 720 (1977).

215 U.S.C. $\S 2$ (1976).

3392 U.S. 481 (1968).

+15 U.S.C. $\$ 13$ (1976). 
tion to its customers, the purchasers of shoes. The Supreme Court rejected this argument, holding that there is no "passing on" defense to a suit by a direct purchaser; the direct purchaser is entitled to get the overcharge back, trebled, whether or not he was really injured to that extent.

Illinois Brick is the mirror image of Hanover Shoe. The plaintiffs in Illinois Brick, represented by the state of Illinois suing on behalf of itself and some 700 local governmental entities in the Chicago area, claimed overcharges in connection with various construction projects. The defendants, manufacturers and distributors of concrete block alleged to be in collusion, sold the block to masonry contractors who submitted bids to general contractors who in turn submitted bids to customers such as the plaintiffs. ${ }^{5}$ The Illinpis Brick plaintiffs were therefore indirect purchasers of concrete block, standing in the same relation to the defendants as the buyers of shoes at retail stood to United Shoe Machinery Corporation. The predicate of the Illinois Brick suit was the passing on of all or part of the overcharge by the direct purchaser; without passing on, there could be no injury to indirect purchasers.

Unless they are willing to countenance multiple liability, ${ }^{6}$ the courts cannot allow suits by indirect purchasers without also permitting the defendant to assert a "passing-on defense" against direct purchaser plaintiffs. As the Court recognized in Illinois Brick, there are only two ways of avoiding unacceptable multiple liability: (1) allow indirect purchasers to sue but overrule Hanover Shoe or (2) retain Hanover Shoe and preclude indirect purchasers from suing. ${ }^{7}$ All legislative attempts to overrule the rule of Illinois Brick recognize that some mechanism must be included to prevent multiple liability. A recent version of such a bill ${ }^{8}$ would have permitted defendants to raise the passing-on defense "in the discretion of the court" in suits by direct purchasers; an earlier version ${ }^{9}$ required the courts to permit the defense. In short, to permit suits by indirect purchasers requires the recognition of a passing-on defense against direct purchasers. ${ }^{10}$ To overrule Illinois Brick is to overrule Hanover Shoe.

s 431 U.S. at 726.

- The Court rejected the option of multiple liability in Hawaii v. Standard Oil Co., 405 U.S. 251 (1972).

I Id. at 736 .

s. 300, 96th Cong., 1st Sess. (1978), reprinted in 899 ANTITRust \& Trade RBg. Rep. (BNA) at A-14 (Feb. 2, 1979). As reported out of committee, the bill dropped the "in discretion" qualification to the passing-on defense.

' S. 1874, 95th Cong., 1st Sess. (1977).

" As the Court pointed out, lower federal courts prior to Illinois Brick that allowed

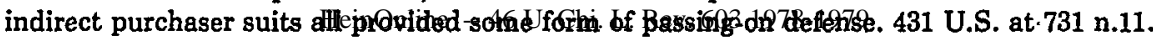


The decision in Illinois Brick was seen in some quarters as a serious setback for private antitrust enforcement, and, as mentioned, there have been efforts to overrule it legislatively." The strongest supporters of this movement are the state attorneys general. The parens patriae bill passed in $1976^{12}$ had given the states the right to bring antitrust treble-damage actions on behalf of consumers in their states but had not, at least expressly, altered the rules of standing. Most such actions were expected to be brought on behalf of indirect purchasers. ${ }^{13}$ By holding that consumers do not have standing to sue remote sellers, the Court in Illinois Brick greatly reduced the number of parens patriae actions that could be brought. ${ }^{14}$

The question whether to overrule Illinois Brick by legislation and allow indirect purchasers to sue has many interesting aspects, such as the feasibility and design of procedural mechanisms for avoiding multiple liability. We, however, address a more fundamental question: assuming the procedural details could be worked out, would the objectives of the antitrust laws be advanced or retarded by allowing indirect purchasers to sue? This question, we believe, can be fruitfully addressed with the assistance of economic analysis. That analysis leads us to conclude that allowing indirect purchasers to sue would probably retard rather than advance antitrust enforcement. The basis for this conclusion lies in the detrimental impact that allowing a passing-on defense would have on enforcement by direct purchasers. ${ }^{15}$

"For a detailed account of this legislative movement see Note, Treble Damages and the Indirect Purchaser Problem: Considerations for a Congressional Overturning of lllinois Brick, 39 Oно ST. L.J. 545 (1978).

1215 U.S.C. \& $15 \mathrm{c}$ (1976).

${ }^{13}$ Handler \& Blechman, Antitrust and the Consumer Interest: The Fallacy of Parens Patriae and a Suggested New Approach, 83 YALE L.J. 626, 632-33 (1976).

14 Cf. Reiter v. Sonotone Corp., 47 U.S.L.W. 4672 (U.S. June 11, 1979) (consumers who pay higher prices for goods sustain injury in "property" actionable under Clayton Act section 4).

15 The question of the effect of allowing indirect purchasers to sue is not only an important one for the student of antitrust policy; it has a broader scholarly interest as an aspect of the general question of private enforcement of law. Economists in recent years have turned their attention to law enforcement and efforts have been made to discuss the conditions under which private law enforcement will yield efficient results. See K. ElzINGA \& W. BREIT, ThE Antitrust Penalties: A Study IN LaW and Economics'(1976); Becker \& Stigler, Law Enforcement, Malfeasance and Compensation of Enforcers, 3 J. Legal STUd. 1 (1974); Landes \& Posner, The Private Enforcement of Law, 4 J. LEGAL STUD. 1 (1975). This paper is a continuation of these efforts with reference to a specific and timely question in the design of optimal systems of private law enforcement. 


\section{The Role of the Compensatory Objective in Analyzing the RULE IN Illinois Brick}

Private antitrust enforcement is traditionally viewed as having two objectives: to compensate victims of antitrust violations and to deter the commission of such violations. When the two objectives come into conflict, however, we believe that achievement of the goals of the antitrust laws requires that deterrence be preferred. If most antitrust violations were deterred, the occasions for compensation would be few. The converse is not true: even if the victims of antitrust overcharges were fully reimbursed, the social inefficiencies of the violations would persist. Therefore, the rule of Illinois Brick is preferable if, as we argue later in this article, it better deters antitrust violations than the alternative rule, even though it denies full compensation to some persons harmed by the violations.

Even if the goal of compensation merited a higher priority in antitrust law than we think it does, overruling Illinois Brick and allowing indirect purchasers to bring antitrust damage actions would not measurably advance that goal. Admittedly, some victims of proven violations are denied legal damages by the rule of Illinois Brick. But those victims obtain, in the form of lower prices, a benefit equivalent to the anticipated value of the antitrust damage claims that they are denied, discounted for the uncertainties of recovery. To explain, consider a simplified distribution chain consisting of suppliers of input $A$, direct purchasers who incorporate $A$ into final product $X$, and consumers of $X$, who are also indirect purchasers of $A$. Suppose the direct purchasers of $A$ suspect the existence of a cartel among the suppliers of $A$. Under the rule of Illinois Brick, the real net price per unit of $A$ will be lower than the stated price charged for $A$ by an amount equal to three times the full estimated amount of the overcharge multiplied by the estimated probability of a successful antitrust suit against suppliers of $A$. This discount or offset reduces the direct purchaser's incentive to substitute away from input $A$, lowers the expected marginal cost of producing $X$, and, crucially, lowers the price of $X$ compared to the case in which no antitrust recovery is anticipated by direct purchasers. The adjustments in the price of $X$ that take place in the market in response to Illinois Brick have the effect of compensating the indirect purchaser of $A$ for the possibility of an illegal overcharge. Compensation takes the form of a lower price for product $X$ as the direct purchaser of $A$ passes on to the indirect purchaser the 
expected value of his antitrust claim against the suppliers of $A .^{16}$

Now consider the impact of reversing Illinois Brick and permitting the indirect purchaser to sue the suppliers of input $A$. The expected value of the direct purchaser's legal claim is reduced because now he is entitled to recover only (three times) the amount of the illegal overcharge that is not passed on. Hence, both the expected price of $A$ and the marginal cost of $X$ will be greater than under the rule of Illinois Brick. As a consequence, the price of $X$ will increase. Purchasers of $X$ will be willing to pay a higher price than before for a given quantity of $X$ because they now have a potential legal claim against the suppliers of $A$. Thus, under a rule reversing Illinois Brick, indirect purchasers pay a somewhat higher price for $X$ in exchange for an entitlement to a possible antitrust recovery.

More broadly, an antitrust claim is equivalent to a valuable, though risky, asset that includes a zero recovery as one possible outcome. Under Illinois Brick, the entire antitrust claim, including the possible zero-recovery outcome, is vested in the direct purchaser. Indirect purchasers are compensated for relinquishing their legal claims by being charged lower prices. The risk of antitrust litigation is borne by the direct purchaser, who may or may not realize a return on his legal claim, while indirect purchasers receive a certain benefit based on the anticipated value of the claim. Overruling Illinois Brick would cause direct and indirect purchasers to share the risk and the possible return on the antitrust claim, and the price of products such as $X$ would increase to compensate the direct purchaser for the lower expected value of his antitrust claim. Thus, the choice between the rule of Illinois Brick or its alternative will affect only the form, and not the amount, of compensation that accrues to ultimate consumers as a group. Moreover, for individual consumers of many different final products over many years, their total level of compensation under Illinois Brick will approximate that under the alternative rule. ${ }^{17}$

16 This argument does not depend on the degree of competition assumed at the directpurchaser level. Even if the direct purchaser were a monopolist, a reduction in his expected marginal cost would lead him to choose a lower profit-maximizing price.

17 Several additional points should be noted. First, the above analysis implicitly assumes that the level of deterrence is independent of Illinois Brick or its alternative. If it is not (and we show in Parts II and III that it is not), then compensation will be affected by the choice of legal rule. For example, if enforcement incentives were sufficiently weakened by overruling Illinois Brick that virtually no price fixers were convicted, then neither direct nor indirect purchasers would be compensated.

Second, our discussion implicitly assumes that purchasers are risk neutral. Thus, the increased price of $X$ that indirect purchasers would pay if Illinois Brick were overruled just equals the expected dollar value per unit of $X$ of their antitrust claim. If risk aversion or 
Of course, some buyers may not anticipate, and thus take account of, possible antitrust recoveries in their purchasing decisions. To the extent that they do not, the force of the foregoing argument is lessened. Even so, there is another independent reason why reversing Illinois Brick is unlikely to advance the compensatory objective of antitrust enforcement. The effect of a price increase due to price fixing or some other antitrust violation tends, as we show later, to be broadly distributed among the suppliers of and the purchasers (mainly ultimate consumers) from the producer whose price increases. Rules of standing that would be unaffected by overruling Illinois Brick will ordinarily bar suppliers from maintaining actions to recover the losses caused them by price fixing. While ultimate consumers could, in principle, obtain damages if Illinois Brick were overruled, normally they could do so only through class actions. But the administrative costs of the consumer class action tend to eat up any damage award or settlement; little compensation may actually trickle down to the individual members of the class. ${ }^{18}$ Nor are parens patriae actions, an alternative to the class-action approach, the answer to this problem. They have the same or similar problems as

preference were a factor, then further refinements in the analysis would be necessary, although the basic result-that compensation is independent of the legal rule-would not be altered significantly. For example, if direct purchasers were risk neutral but indirect purchasers (consumers) were risk averse, overruling Illinois Brick would lead to a smaller increase in the price of $X$ because indirect purchasers would be receiving a risky asset (i.e., their antitrust claims) in exchange for a higher price, with certainty, of $X$.

Third, bringing anticipation of antitrust damages into the analysis has implications for resource allocation as well as for compensation. For example, if the probability of discovering and successfully prosecuting price-fixing suppliers is one-third, then under Illinois Brick or its alternative the value of the deadweight loss from a monopoly or cartel price will approach zero. To illustrate, if the illegal overcharge per unit of $A$ is $\$ 1$, then the expected value of the antitrust recovery under Illinois Brick would equal $\$ 1(=(1 / 3) \$ 1(3))$ and hence the expected price of $A$ and marginal cost of $X$ would not change compared to the precartel level. Since this would leave the output of $X$ constant, the deadweight loss from the cartel would approach zero. (Deadweight losses would still be positive since enforcement expenditures by plaintiffs and defendants consume real resources.) Deadweight losses will also result when the expected value of the antitrust recovery differs from the size of the illegal overcharge. For example, if the former were less than the latter, direct purchasers would substitute away from $A$, the expected marginal costs and price of $X$ would increase, and the output of $X$ would fall below the precartel level. Alternatively, if the expected value of the recovery were greater than the illegal overcharge, the price of $X$ would fall and output would rise relative to the precartel level. In both cases, resources would be inefficiently allocated and deadweight losses would occur. Although the level of compensation of indirect purchasers would depend on the relationship between the size of the expected antitrust recovery and the illegal overcharge, the distribution of compensation between direct and indirect purchasers would still be independent of Illinois Brick or its alternative.

is 431 U.S. at 747 n.31; Dam, Class Actions: Efficiency, Compensation, Deterrence and Conflict of Interest, 4 J. Legal Stud. 47, 56-61 (1975); Posner, An Economic Approach to Legal Procedure and Judicial Administration, 2 J. Legal Stud. 399, 440 (1973). 
class actions with respect to notice, opting in or out, and allocation and distribution of damage awards. ${ }^{19}$

Other indirect purchasers, such as retailers in a two-tiered (wholesale and retail) distribution system, may be in a better position to collect a meaningful judgment than the ultimate consumer. But since they, like direct purchasers, will often be able to pass on much of the cost of an unlawful price increase to their customers and suppliers, allowing them to sue may not substantially further the compensatory objective either. Moreover, if, as we argue below, ${ }^{20}$ overruling Illinois Brick would probably reduce the overall deterrent efficacy of antitrust enforcement, the benefits that some consumers might obtain from being allowed to bring indirect-purchaser class actions could be offset by the costs to other consumers, who would pay higher prices because of the increased number of antitrust violations.

\section{The Effect on Deterrence of Allowing Indirect Purchasers to SuE: Theoretical Considerations}

Having shown that overruling Illinois Brick is unlikely to have much effect in promoting the compensatory objective of the antitrust laws-even assuming that compensation is a significant objective of the antitrust laws when in conflict with the deterrent objective of those laws-we turn to the question of the likely impact on deterrence of overruling Illinois Brick. The most important consideration from the standpoint of deterrence is not who receives the proceeds of any judgment levied against the antitrust violator, but that there be adequate incentives to bring suit and prosecute it to judgment. ${ }^{21}$ This objective is more likely to be achieved by the rule of Illinois Brick, which favors direct-purchaser suits, than by a rule favoring indirect-purchaser suits. First, the direct purchaser is a more efficient enforcer of the antitrust laws than the indirect pur-

19 See generally Handler \& Blechman, supra note 13. As the Supreme Court has pointed out, Congress did not expect the parens patriae legislation to result in recoveries of small claims by individual consumers; rather, undistributed portions of the damages would be sizable and would be added to state revenues or used for other public purposes. 431 U.S. at $747 \mathrm{n} .31$. The benefits to the actual victims of the price fixing from these uses of the damages would often be negligible.

${ }^{20}$ See Parts II \& III infra.

21 This assumes that the judgment approximates the social costs of the violation, adjusted to reflect the probability that the violator will be brought to bar. If that probability is less than one, the judgment should be larger than the estimated social costs of the violation so that the expected cost of punishment to the antitrust violator will equal the estimated social costs. This is the economic rationale of trebling. 
chaser and should therefore be given maximum incentive to bring antitrust suits. Second, the problem of apportioning damages among direct and indirect purchasers would be so costly that it would decrease the incentives of any purchaser to sue. Third, even if direct and indirect purchasers were equally efficient antitrust enforcers, and even if allocation problems could be solved without seriously depleting the recovery pool, deterrence would be weakened if the right to sue were divided among more parties so that each claim was relatively small.

\section{A. Relative Information Costs of Direct and Indirect Purchasers}

The direct purchaser is a more efficient enforcer of the antitrust laws than the indirect purchaser because of the former's closer proximity to the violator. The direct purchaser deals directly with the violator, and probably with his competitors, and he is therefore in a better position than a more remote purchaser to detect a conspiracy or other antitrust violation. The remote purchaser may not know that a price increase to him is attributable to a price increase by a remote supplier, and even if he does know, he will find it difficult to discover the reasons for the remote supplier's price increase.

Not only does the remote purchaser lack direct knowledge of the business of the supplier who has raised prices, he must also undertake efforts (unnecessary for a direct purchaser) to determine which remote supplier is responsible for the price increase. To explain, assume that the producers of product $A$ fix the price at a level above the competitive price. Product $A$ is an input into a product that ultimately reaches consumers after successive stages in the production distribution chain. Assume further that producers of $A$ are located at point $n$ on the distribution chain; producers using $A$ are located at point $n-1$; and the consumer is located at point 0 , as in Figure 1.

consumer

producer of

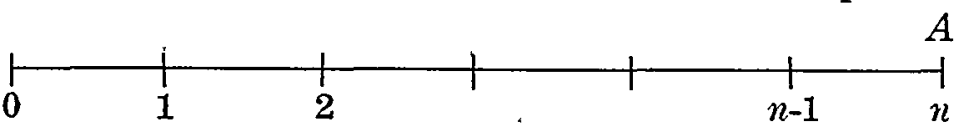

Figure 1

For example, if $n=4$, at point $n$ are raw material producers fixing prices, at $n-1$ are manufacturers (the direct purchasers), and at $n$ $2, n-3$ and $n-4(=0)$ are wholesalers, retailers, and final consumers (the indirect purchasers), respectively. 
Since the increase in the price of $A$ will be transmitted through the entire distribution system, each purchaser will experience an increase in the price charged by one of his suppliers-the supplier who connects him to the distribution chain that originates with the producers of $A$. Each purchaser, however, will be uncertain about the cause of the price increase. It may be due to a price-fixing agreement entered into by his supplier or simply to legitimate increases in his supplier's costs, such as an increase in the price of some input into the supplier's product. The purchaser will have to invest resources to determine which of the two alternative explanations of the price increase is correct. If the legal rule entitles only the direct purchaser from the antitrust violator to sue, each purchaser in the distribution chain will investigate only the link or stage in the chain directly above him. Since there are $n$ links in the chain (from 0 to point $n-1$ in Figure 1 ), the maximum number of searches that will take place before the price-fixing scheme is uncovered is $n .^{22}$

But suppose the legal rule is modified to permit any purchaser, direct or indirect, to recover damages from the fixing of the price of $A$. Now a purchaser at any point $j$ on the distribution line will have an incentive to search for information on price fixing not only at point $j+1$ but also at points $j+2, j+3, \ldots, n$. If, for example, each firm on the distribution line in Figure 1 produces its output using two inputs supplied by two different suppliers, then purchasers at $j$ will search over one input supplier at $j+1$, two input suppliers at $j+2$, two at $j+3, \ldots$. , and two at $n .{ }^{23}$ To uncover the price-fixing scheme at $n$, therefore, purchasers at $j$ would have to search over $2(n-j)-1$ suppliers. Since purchasers at each stage in the distribution chain have a similar incentive to search over suppliers above them in the distribution chain, one can show that, when indirect purchasers are permitted to recover damages, the maximum number of

22 In terms of Figure 1, consumers at point 0 will search over firms at point 1 , firms at 1 will search over firms at point 2, and so forth. Assuming that each firm searches, the aggregate number of searches is $n$ times the average number of firms or persons searching at each point. To simplify, we define a unit of search as all search activity from point $i$ to $j(i \neq j)$ on the distribution chain.

${ }^{23}$ The reason that the purchaser at $j$ searches over one supplier at $j+1$ but two each at $j+2$ through $n$ is that, although his direct supplier's price has risen, he lacks information on which of the two inputs produced at $j+2, \ldots, n$ has increased in price. Suppose each firm in the distribution chain were supplied by two different firms, and a searcher had to search over all firms at each point in the distribution chain. In this case, $j$ would search over 1 supplier at $j+1,2$ at $j+2,4$ at $j+3,8$ at $j+4$, and up to $2^{n-j-1}$ at $n$. This would imply, for example, that if $n=4$, ultimate consumers might have to search over 15 suppliers (compared to 7 in the analysis in the text) to discover the price fixer. 
searches equals $n^{2} .{ }^{24}$

Searching for an antitrust violation is, of course, a costly activity. If each unit of search costs $\$ X$, then in the above example it will cost in the aggregate at most $n \$ X$ to uncover the price-fixing agreement when the legal rule gives the direct purchaser the exclusive right to recover, and at most $n^{2} \$ X$ when the rule allows indirect purchasers also to recover. Thus, as a first approximation, the indirect-purchaser rule increases the aggregate costs of searching for an antitrust violation by the amount $\left(n^{2}-n\right) \$ X$ compared to the direct-purchaser rule. ${ }^{25}$ This means that if, for example, there are four stages in the distribution chain-as there would be where the price fixer sold some input to a manufacturer (stage 1), who incorporated it into a product that he sold to a wholesaler (stage 2), who resold to a retailer (stage 3 ), who resold to the final consumer (stage 4) - so that $n=4$-then (if there are two inputs at each stage) the cost of searching for the antitrust violation could be fifteen times as great under a rule allowing indirect purchasers to sue than under the rule of Illinois Brick. From the social point of view this added expenditure is a waste of resources since, by assumption, the antitrust violation is discovered under either rule.

21 The maximum number of searches equals

$$
\begin{aligned}
S \max & =\sum_{j=0}^{n-1}[k(n-j-1)+1] \\
& =n\left(\frac{n k}{2}-\frac{k}{2}+1\right)
\end{aligned}
$$

where $k$ is the number of inputs supplied at each point. When $k=2, S \max$ simplifies to $n^{2}$.

${ }^{25}$ We say "as a first approximation" advisedly. The difference in aggregate search costs may be less or more than $\left(n^{2}-n\right) \$ \mathrm{X}$. They may be less for two reasons:

(1) The costs of an unsuccessful search are likely to be less than the costs of a successful one because the former will exclude various litigation expenditures once it is determined that the supplier was not fixing prices. If we let $\$ Y$ equal the costs of an unsuccessful search and $\$ X$ equal the costs of a successful one, then aggregate costs are $\$ X+(n-1) \$ Y$ and $n \$ X+$ $\mathrm{n}(\mathrm{n}-1) \$ Y$ under the direct and indirect-purchaser rules respectively. The difference between them is $(n-1) \$ X+(n-1)^{2} \$ Y$ which is obviously less than $\left(n^{2}-n\right) \$ X$ provided $\$ X>\$ Y$.

(2) When indirect purchasers are allowed to recover, there is an incentive for the various parties to avoid costly duplication of effort by agreeing to restrict their search activity, share in all search costs, and pool all information that is acquired. This would approach the result of the direct-purchaser rule if the various parties agreed to restrict their activity to their direct suppliers only. Since the costs of reaching a full agreement are positive and probably prohibitive (because the interests of the parties will diverge on other issues such as the extent of passing on), the costs of the indirect-purchaser rule will always be greater than that of the direct-purchaser rule. 
This analysis can be made more concrete by reference to the facts of the Illinois Brick case itself. The alleged price fixers were manufacturers of cement blocks who sold them to masonry contractors who supplied their services to general contractors who in turn sold buildings incorporating the cement blocks to the ultimate consumers. For those consumers to have identified the source of the added cost of buildings (assuming they even noticed the added cost due to the price fixing of cement blocks) would have required them to study the conduct of the general contractors, identify their suppliers, and trace the inputs used by those suppliers to their ultimate source. Only then would the consumers have identified the manufacturers of cement blocks as the ultimate source of their injury. This would have been a highly complicated and expensive search process compared to what the masonry contractors-the direct purchasers of the cement blocks - would have had to undertake in order to determine that the manufacturers of the blocks were engaged in price fixing. ${ }^{26}$

The availability of a passing-on defense will often have the effect of reducing the incentive to sue of intermediate purchaserswhose potential claims might otherwise be larger-to a point below the level at which litigating would be an attractive option. Therefore, if indirect-purchaser suits are permitted, those indirect purchasers who sue will ordinarily be ultimate consumers whose small claims can be vindicated only through the medium of class actions. But class action suits are unsatisfactory enforcement devices because the lawyers who represent consumer class-action plaintiffs

There is a factor that works in the direction of increasing the relative costs of the indirect purchaser compared to the analysis in the text, however. We assumed constant costs of search at each stage of the distribution chain ( $\$ X$ in the text and a combination of $\$ X$ and $\$ Y$ in this footnote). If the number of parties searching decreases as one goes from point 0 (the ultimate consumer) to point $n-1$, the costs of search are likely to decrease as well. This, in turn, will widen the difference in search costs between the indirect and direct-purchaser rules.

${ }^{26}$ Of course, class actions comprising ultimate consumers were brought in Illinois Brick, but it does not follow that the consumers, or their class representative, undertook any such complicated search process. They may have "piggybacked" on direct-purchaser plaintiffs or, since the state represented the class, obtained information of the antitrust violations from a government investigation or complaint. Indeed, the very cost of the search process described above, especially for ultimate consumers, makes it unlikely that such searches are often undertaken, and thus biases reported cases in favor of those where indirect purchasers learn of their remote suppliers' behavior through serendipitous means. But where this is so, the entitlement of purchasers who have not borne any of the costs of investigation to share in the damages awarded reduces the incentives of other more favorably situated potential plaintiffs, such as direct purchasers, to bear those costs. This point is developed at pp. 621-25 infra. 
appear to lack adequate incentives to press for the largest possible judgment, even in meritorious cases. Their interests may be better served by agreeing to a settlement that provides for a relatively small judgment but large attorneys' fees-a settlement result also attractive to defendants. ${ }^{27}$ The individual class member's stake is too small to give him any incentive to supervise the lawyer for the class, so the usual checks on a lawyer's conflict of interest with his client are lacking. ${ }^{28}$ It does not follow that the consumer class action has no deterrent effect, but its deterrent effect may be less than that of first-purchaser suits.

Nor is the recently authorized parens patriae suit the answer to the problem of deterrence. Given the political character of parens patriae enforcement, it is doubtful that it can be relied upon as an adequate antitrust deterrent. There may well be a tendency under parens patriae for state attorneys general to bring headlinegrabbing, scapegoat-seeking suits against politically unpopular corporations, with little regard for the intrinsic antitrust merit of the suit and with little effort to press the suit to a successful conclusion. By the time the case is ready for trial, the state attorney general's office may be occupied by a new politician with little interest in carrying out the projects of his predecessor.

The only argument we have heard that direct purchasers may be less efficient enforcers than indirect purchasers is that the first purchaser may be reluctant to sue his supplier lest an ongoing relationship beneficial to the purchaser be disrupted. ${ }^{29}$ This argument overlooks the fact that the direct purchaser's acquiescence in his seller's antitrust violations will normally be a compensated acquiescence. A rational profit-maximizing firm will not abandon a legal right with some dollar value unless it receives concessions of equivalent value. From the standpoint of deterring antitrust viola-

" See Posner, supra note 18, at 440-41. For empirical support of this proposition see Rosenfield, An Empirical Test of Class-Action Settlement, 5 J. Legal Stud. 113 (1976), finding that attorneys' fees in antitrust class actions are greater when cases are settled than when they are tried, holding constant the amount of damages awarded the class. This pattern is suggestive of the kind of "deal" that we worry about in such actions.

${ }^{23}$ Although the court exercises supervision over the settlement of class actions, this supervision can hardly be as effective as that of an interested client over his attorney.

2s Illinois Attorney General William Scott, a major proponent of legislation to overrule Illinois Brick, has stated:

Unless our office and the other Attorneys General have the authority to protect the tax dollars of our citizens from these antitrust violators, no one will. Contractors and other middlemen who sell commodities to governmental entities have no real incentive to sue their suppliers for illegal overcharge and risk their availability of supplies when they can and do pass along the inflated cost.

Newsletter from W. Scott, Attorney General, State of Illinois (May 3, 1979). 
tions, these concessions constitute a form of antitrust damages. If a supplier wants to buy his purchasers' silence, the price he will have to pay is, in effect, his punishment for the illegal activity that he is trying to conceal. That price will be greater under the Illinois Brick rule because the expected value of the direct purchaser's antitrust claim is greater when no part of the recovery is distributed to indirect purchasers. Overruling Illinois Brick would reduce the price of the direct purchaser's silence, and thereby reduce the expected costs of price fixing and hence the deterrent effect of private enforcement.

In any event, the idea that purchasers are bashful about suing their suppliers is today unrealistic, almost quaint. Firms now bring antitrust suits at the drop of a hat-and are subject to severe criticism, and potentially to shareholders' derivative actions, if they forgo an opportunity to bring a meritorious suit. Nor is it realistic to think that potential antitrust plaintiffs fear retaliation by a sued supplier: retaliation would simply clinch the plaintiff's original case as well as give him an additional antitrust cause of action. Empirical evidence on the alleged reluctance of purchasers to sue their suppliers is difficult to obtain. But the large number of private antitrust suits alleging price fixing that are brought each year, most of which are direct-purchaser suits, ${ }^{30}$ provides at least suggestive evidence in support of our view that direct purchasers are not reluctant to sue their suppliers.

If we are correct that the first purchaser is the more efficient enforcer of the antitrust laws than the indirect purchaser, it follows that the rules of standing should be designed in such a way as to give the direct purchaser the maximum incentive to sue. The rule of Illinois Brick accomplishes this by allowing the direct purchasers to sue for treble the entire overcharge, ${ }^{31}$ without subtracting the

30 Evidence on the relative importance of direct and indirect-purchaser suits is available in the appendices to written statements in Fair and Effective Enforcement of the Antitrust Laws: Hearings on S. 1874 Before the Subcomm. on Antitrust and Monopoly of the Senate Comm. on the Judiciary, 95th Cong., 2d Sess., pt. 2 (1978). For example, a study of antitrust cases in the Southern District of New York in 1977 indicated that out of a total of 69 suits brought by purchasers, 66 , or 96 percent, were direct-purchaser suits, id. at 26-31. A similar study of 197 pending cases in the Northern District of California showed that out of a total of 163 purchaser suits, 67 percent were direct-purchaser suits, 23 percent were indirectpurchaser suits, and the rest involved both direct and indirect purchasers, id. at 361-72. A study of 53 pending cases in the District of Arizona revealed that out of a total of 32 purchaser suits, 81 percent were direct-purchaser suits, 3 percent were indirect, and the rest involved both direct and indirect purchasers, id. at 375-78.

${ }^{31}$ Actually, the overcharge paid by the purchaser understates the social costs of the antitrust violation. It ignores both the injury to those who stop purchasing the product because of the price increase and the possibility that the antitrust violation may have raised 
amount of that overcharge passed on to more remote purchasers. Unless multiple liability is to be created, an indirect-purchaser suit necessarily weakens-and at the extreme eliminates-the incentive of the first purchaser to sue, by decreasing his recovery. Thus, the question is presented whether the predictable reduction in the incentive of direct purchasers to sue if Illinois Brick were statutorily overruled would be outweighed by the predictable increase in the incentive of indirect purchasers to sue. Since the first purchaser is the more efficient (lower cost) enforcer, the answer to the question is "no."

\section{B. Implementing a Passing-On Defense}

As noted above, overruling Illinois Brick would imply restoring the passing-on defense that was rejected in Hanover Shoe. It is this feature that leads to the undesirable incentive effects discussed above. In addition, the implementation of a passing-on defense, that is, the apportionment of damages among the various tiers in the distribution chain, would involve extremely difficult problems of economic analysis and measurement. Efforts to solve these problems would make antitrust litigation even more cumbersome than it is already and thereby directly reduce the efficiency of the enforcement process.

- Let us examine the mechanics of apportioning the antitrust overcharge among the levels of distribution. When a firm is charged a higher price for one of its inputs (input $A$ ) because of an antitrust violation, its costs increase. The firm will try to offset the increase by raising its price. If its competitors are not affected by the cost increase, the attempt will fail ${ }^{32}$ and the firm will either go out of business or contract its output (if by so doing it can lower its costs). Since, by assumption, there is no possibility of the firm's passing on the increased price of $A$ to its indirect purchasers, the question of apportionment of damages does not arise. ${ }^{33}$ But in the more typical case, and the one we shall focus on here, the increase in the price of input $A$ affects not just a single firm but an entire industry (or several industries). That is, all the sellers of a particular product

the costs as well as price of the violator's product. These refinements do not affect the point made here.

${ }^{32}$ When a seller faces a significant number of competitors, the elasticity of demand for its product will be high, meaning that even a small increase in its price will drive customers to substitute a competitor's product. p. 621.

${ }^{33}$ The firm may be able to pass on part of the price increase in $A$ to its suppliers. See 
(product $X$ ) pay the higher price. Because the industry faces a downward-sloping demand curve for $X$, the reduction in supply brought about by the cost increase will generate a higher price for $X$. This is illustrated in Figure 2. The increase in the price of input $A$ to the producers of $X$ (the direct purchasers) shifts the industry supply curve (which is also the industry marginal-cost curve) upward from $S$ to $S^{\prime}$, resulting in a price increase from $P_{x}$ to $P_{x}^{\prime}$ to the indirect purchasers of $A$ and a fall in output from $X$ to $X^{r}$

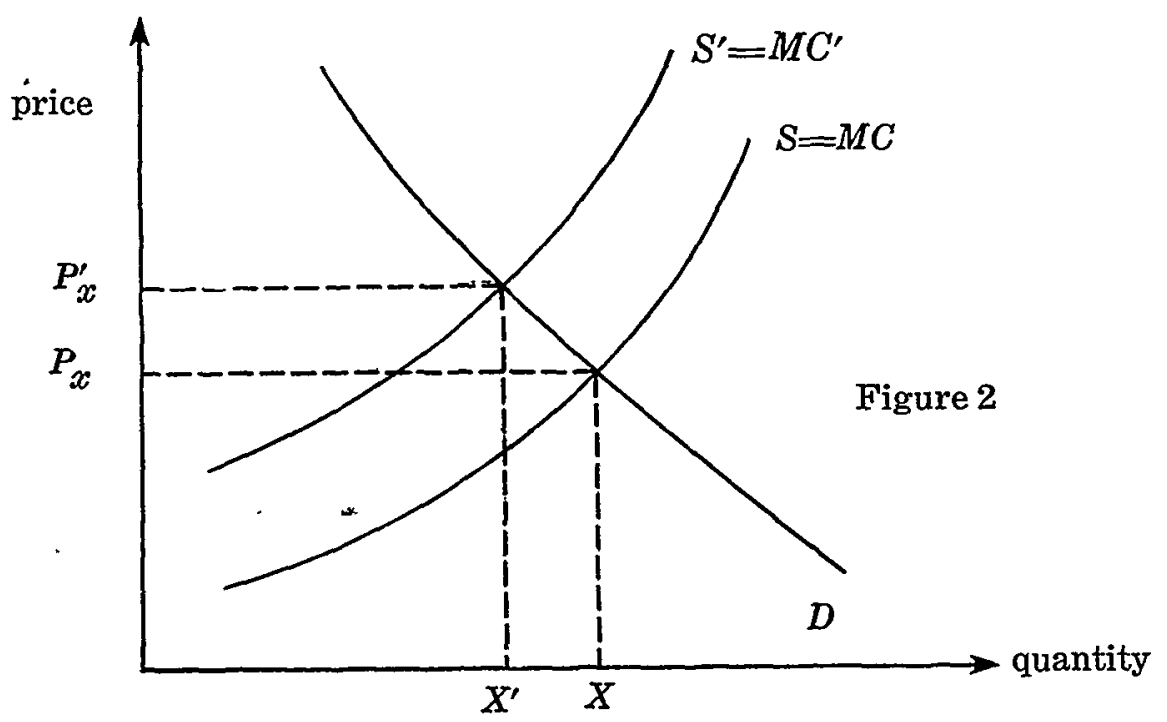

Notice in Figure 2 that the proportional shift in the marginal cost curve at a given output is less than the proportional increase in the price of input $A$. That is,

$$
\widetilde{M C}=\ddot{\delta}_{a} \widetilde{P}_{a}
$$

where $\widetilde{M C}$ and $\widetilde{P}_{a}$ denote the percentage increases in marginal cost (at a given output) and price of $A$ respectively, andi $\delta a$ equals the share of input $A$ in the marginal costs of $X .{ }^{34}$ For example, if input

34 See G. Becker, Economic Theory 142-43 (1971). Equation (1) holds only when the price of other inputs in the production of $A$ remains constant. If the price of other inputs on average increases as producers of $X$ attempt to substitute away from $A$ when its price increases, then $\widetilde{M C}>\delta_{a} P_{a}$. To simplify the presentation we shall assume that (1) does hold. 
$A$ 's share of marginal cost is 20 percent and the antitrust violation increases $P_{a}$ by 10 percent, then the marginal-cost curve in Figure 2 will shift upward by 2 percent. ${ }^{35}$

Even if we cannot observe directly the increase in the price of $X$ due to the shift in marginal cost when $P_{a}$ increases because other factors operate simultaneously to affect the price of $X$, we can calculate the magnitude of the increase in marginal cost that is shifted to demanders of $X$ provided we have information on the elasticities of both demand and supply. If we denote the proportional increase in the price of $X$ to indirect purchasers by $\widetilde{P}_{x}\left(=\left(P_{x}^{\prime}-P_{x}\right) / P x\right)$, it can be shown that

$$
\widetilde{P}_{x}=\widetilde{M} \boldsymbol{M} e^{s} /\left(e^{s}+e^{d}\right)
$$

where $e_{s}$ and $e_{d}$ are the supply and demand elasticities respectively. ${ }^{36}$ Substituting from equation (1) yields

$$
\tilde{P}_{x}=\delta_{a} \tilde{P}_{a} e^{s} /\left(e^{s}+e^{d}\right) \text {. }
$$

Most estimates of elasticities of demand and supply are in the range of zero to one. (An elasticity of demand of one would mean, for example, that a one percent increase in price would lead to a one percent decrease in the quantity demanded.) If, for example, $e^{s}=.4$ and $e^{d}=.8$ and we assume that input $A$ 's share of marginal cost is 20 percent, then equation (3) shows that a 10 percent increase in the price of $A$ will result in less than a one percent increase (.67 percent) in $P_{x}$. Even if we reverse the elasticities, letting $e^{s}=.8$ and $e^{d}=.4$, the increase in $P_{x}$ is only 1.33 percent. Thus, indirect purchasers face a negigible increase in price in comparison to a direct purchaser whose input price increases by 10 percent.

This example is pertinent to the analysis of relative enforcement efficiencies because it suggests that the impact of price fixing on the indirect purchaser will be relatively small and therefore difficult for him to detect. When this factor is combined with the reduction in enforcement incentives of direct purchasers that results from their having to divide damages with any indirect purchasers who do sue, the possibility arises that no party will expend sufficient resources to uncover the price-fixing scheme.

Further, although our analysis indicates that the proportional increase in the price to the indirect purchaser will ordinarily

${ }^{35}$ Our analysis in this section considers the apportionment of damages between direct and indirect purchasers on the assumption that neither party takes into account possible antitrust recoveries in their purchasing decisions. But see note 17, supra.

34 See C. Shoup, Public Finance 273-74 (1969). 
be relatively small, this does not imply that direct purchasers would receive the lion's share of the damage recovery if the suit succeeded, and therefore that their incentive would not be substantially affected by the possibility of indirect-purchaser suits. The proportional increase in marginal cost that is not passed on to the indirect purchaser equals

$$
\widetilde{M C}-\widetilde{P}_{x}=\delta_{a} \widetilde{P}_{a} e^{\dot{d}} /\left(e^{s}+e^{d}\right)
$$

and the ratio of the proportional increase in price to the indirect purchaser to the proportional increase in marginal cost absorbed by the direct purchaser resulting from the increased price of $A$ is given by

$$
\tilde{P}_{x} /\left(\widetilde{M C}-\tilde{P}_{x}\right)^{\prime} \stackrel{r}{=} e^{s} / e^{d}
$$

If we let

$$
\dot{\lambda}=\text { share of recovery (three times damages or over- }
$$
charge) received by direct purchaser,

and

$1-\lambda=$ share of recovery received by indirect purchaser, and assume that the indirect purchaser's share in damages is proportional to the amount passed on, it follows that $(1-\lambda) / \lambda=e s / e d$, or

$$
\lambda=e^{d i}\left(e^{d}+e^{s}\right)
$$

and

$$
1-\lambda=e^{s} /\left(e^{s}+e^{d}\right) .
$$

Thus, when $e^{d}=.4$ and $e^{s}=.8$, the indirect purchaser will receive two-thirds of the total recovery even though the price to him increases by only 1.33 percent. ${ }^{37}$ The party with the largest stake in the recovery (the indirect purchaser) experiences a negligible increase in price, making it difficult for him to detect the antitrust violation. The party in the best position to detect the violation (the direct purchaser) has little incentive to do so because of his relatively small stake in any damage recovery.

Our emphasis has been on the potentially deleterious effect on the incentive to bring private antitrust suits of requiring apportionment of damage recovery among the direct and indirect purchasers. The cost and difficulty of making that apportionment present a

${ }^{37}$ Of course, if there are many indirect purchiasers, as is usually the case, the portion of the total recovery allocated to each indirect purchaser will be very small. 
separate issue. In particular, apportionment requires knowledge of the elasticities of supply and demand. Although econometric techniques are available that can, in principle, be used to estimate point elasticities, there are many practical difficulties with such estimations. ${ }^{38}$ We are fearful of the increase in the costs, time, and uncertainty involved in antitrust enforcement if the passing-on issue is injected into suits by direct or indirect purchasers. Four considerations make the calculation of elasticities especially difficult.

First, although it is sometimes possible to estimate with a fair degree of precision either a demand or a supply elasticity, it is exceedingly difficult to estimate both. Demand estimation is facilitated when demand is relatively constant but supply is shifting, so that the interactions between the (different) supply curves and the (constant) demand curve enable the points on the demand curve to be plotted. Under these conditions, however, with supply shifting, the estimation of the supply curve is difficult. Conversely, where supply is constant but demand shifting, the estimation of the supply curve is facilitated because the intersections between the (constant) supply curve and the (different) demand curves enable points along the supply curve to be plotted. But then the estimation of demand is difficult. Trying to identify both demand and supply curves is often a statistical nightmare. ${ }^{39}$

Second, the formulas derived above are valid only for small changes around the initial equilibrium point. Typically, elasticities will vary at different points along the supply and demand curves, thus adding another degree of complexity to the estimation process. Third, when there is only one class of indirect purchasers, only two elasticity estimates are required, but each time an additional class is added, two more elasticity estimates are required. Thus, statistical problems multiply as the distribution chain lengthens. Finally, elasticities depend on the amount of time buyers and sellers have in which to adjust to the price change. If there is a lag between the price-fixing agreement and its discovery (as there must be for dam-

${ }^{38}$ Elmer J. Schaefer, who also uses the concepts of supply and demand elasticity to analyze passing-on questions, see Schaefer, Passing-On Theory in Antitrust Treble Damage Actions, An Economic and Legal Analysis, 16 WM. \& MARY L. REv. 883 (1975), is much more confident than we are of the feasibility of using elasticity estimates to apportion damages between direct and indirect purchasers. He seems to assume that the sorts of elasticity estimates made in the academic economic literature could be readily duplicated in antitrust litigation. See id. at 915-16 \& nn.125-26. Yet he does not cite, nor do we know of, a single case in which an antitrust court has attempted to estimate an elasticity of demand or supply.

3" For a classic statement of these difficulties see Working, What Do Statistical 'Demand Curves' Show?, 41 Q.J. Econ. 212 (1927), reprinted in REAdINGS IN PRICE THEORY 97 (G. Stigler \& K. Boulding eds. 1952). 
ages to occur), the amount of passing on in each period will depend on the relative changes in the demand and supply elasticities. Accurate apportionment will then require estimating the changes in elasticities over time.

In short, constructing the empirical counterparts of the curves in Figure 2 in an individual case would present severe difficulties of proof. There would be a serious danger of inconsistent determinations of the key parameters in the various indirect-purchaser actions, raising the specter of multiple recovery in some cases and inadequate recovery in others. The alternative would be massive and potentially unmanageable consolidation of a myriad of separate claims. In this perspective, a considerable advantage of the directpurchaser action is that ordinarily the number of direct purchasers from a particular supplier is many fewer than the number of indirect purchasers, thus facilitating effective antitrust enforcement.

Our concern with encumbering the trial of antitrust cases with incidence analysis is not aesthetic in character; nor is it based on a distaste for introducing economic analysis into antitrust litigation. But the injection of difficult empirical economic issues into an antitrust suit is a source of added cost and uncertainty. It is a step that should not be taken where, as in this context, it promises no increase in the effectiveness of antitrust enforcement.

A further point should be noted. Were it feasible to measure elasticities of demand and supply, as required to implement a passing-on defense, the implications for the trial of antitrust cases in general would be revolutionary. For example, it is the assumed infeasibility of measuring the elasticity of demand for a firm's product that underlies the requirement, in merger, monopolization, and other kinds of antitrust cases, of proving a relevant market. A relevant market is simply a group of sellers assumed not to face strong competition from other sellers, because no other sellers sell a close substitute for their product. From this it is inferred that the group has power to raise prices above the competitive level. But this conclusion is just a very crude way of saying that the elasticity of demand for the sellers' product is relatively low. If that elasticity could be measured directly, such measurement would provide a much more direct and precise method of gauging monopoly or market power than defining a relevant market and computing market shares. ${ }^{40}$ Proponents of overruling Illinois Brick and Hanover Shoe should ask themselves whether they really believe that the measure-

10 See R. Posner, Anttrrust Law: An Economic Perspective 125 (1976). 
ment of supply and demand elasticities by the methods of litigation is so far advanced that we can jettison relevant-market determination in antitrust litigation as an appropriate corollary to overruling the cases that reject the passing-on defense as infeasible."

Although our analysis in this section has stressed enforcement costs and incentives, it can also tell us something about compensation. If Illinois Brick were overruled, the ultimate indirect purchaser-the consumer-could recover for the illegal overcharge, at least if incentive effects and administration costs are ignored. But other indirect purchasers and the direct purchaser, all of whom may receive a share of the recovery, may not be injured, while some people who are injured may not be allowed to recover. For example, in the process of adjusting to the increased price of input $A$, the direct purchaser may both decrease production and substitute towards other inputs. So long as these inputs have supply curves that are not perfectly elastic, their prices will increase or decrease depending on the relative size of the substitution and output effects. Since no one proposes that buyers or sellers of complementary or substitutable inputs be given rights to sue, it follows that many injured parties will not recover damages for antitrust violations even if Illinois Brick is overruled.

C. Adverse Consequences of Allowing Both Direct and Indirect Purchasers to Sue Even If They Are Equally Efficient Antitrust Enforcers

Even assuming (unrealistically, as the above analysis indicates) that direct and indirect purchasers have identical total and marginal costs of enforcement, a legal rule that apportions the recovery according to the damages suffered by each party will weaken deterrence. To simplify the analysis, assume that there are only three parties in the distribution chain: an indirect purchaser (consumer), direct purchaser (retailer), and supplier (manufacturer). Assume further that price fixing occurs at the manufacturing level, and as before let $\lambda$ and $1-\lambda$ equal the share of recovery received by the direct and indirect purchasers respectively. Finally, assume that the recovery does not include reimbursement of attorneys' fees

"For another example of how, if one were confident of economists' ability to make relatively precise estimates of elasticities, antitrust enforcement would be transformed, consider the following: if the price elasticity of demand were relatively high for a product, then a cartel would be unable to raise price much above the competitive level. Since enforcement resources are scarce, it would make little sense in this instance to punish such a conspiracy. The per se rule against price fixing could be discarded. 
or other litigation expenses, an assumption that will not affect our results.

If the legal rule permitted recovery only by the direct purchaser, which is the rule of Illinois Brick, $\lambda$ would equal 1. Although the indirect purchaser would have no incentive to spend resources on enforcement, this rule would maximize the direct purchaser's incentive. In deciding on his optimal enforcement expenditures the direct purchaser would attempt to maximize $\pi^{d}+$ the difference between his expected recovery and his costs of enforcement. Formally, he would maximize

$$
\pi^{d}=p R-C^{d}(y)
$$

which requires choosing a level of enforcement expenditures such that

$$
p_{y} R^{\prime}-C_{y}^{d}=0
$$

where $p$ is the probability of discovering and convicting the antitrust violator, $R$ the recovery, $G d$ the direct purchaser's enforcement costs, and $y$ the inputs of enforcement resources. ${ }^{42}$ Both $p$ and $G d$ are assumed to be positive functions of the inputs of $y-$ i.e., $p=$ $p(y)$ and $C d=C d(y)$ where an increase in $y$ increases both the probability of apprehending and convicting the violator $\left(p_{y}>0\right)$ and the costs of enforcement $\left(C_{y}^{d}>0\right)$. Put;differently, $p_{y} \bar{R}$ and $C_{y}^{d}$ denote respectively the marginal returns and marginal costs of enforcement with respect to an increment in $y$, and equation (9) states that in equilibrium the enforcer will equate marginal returns to marginal costs. This is illustrated in Figure 3 where $\hat{y}$ equals the equilibrium level of $y .{ }^{43}$.

12 Note that $y=\mathrm{y} d+y i$ where $y d=$ the direct purchaser's inputs and $y i$ the indirect purchaser's inputs. Since $y^{i}=0$, we have $y=y^{d}$.

${ }^{43}$ We assume that the second-order conditions for a maximum are also satisfied when $p_{y} R-C_{y}^{d}:=0$. This would occur, for example, if there were diminishing marginal returns from enforcement and constant or increasing marginal costs. To simplify the presentation we assume diminishing marginal returns and constant marginal costs. 
Figure 3

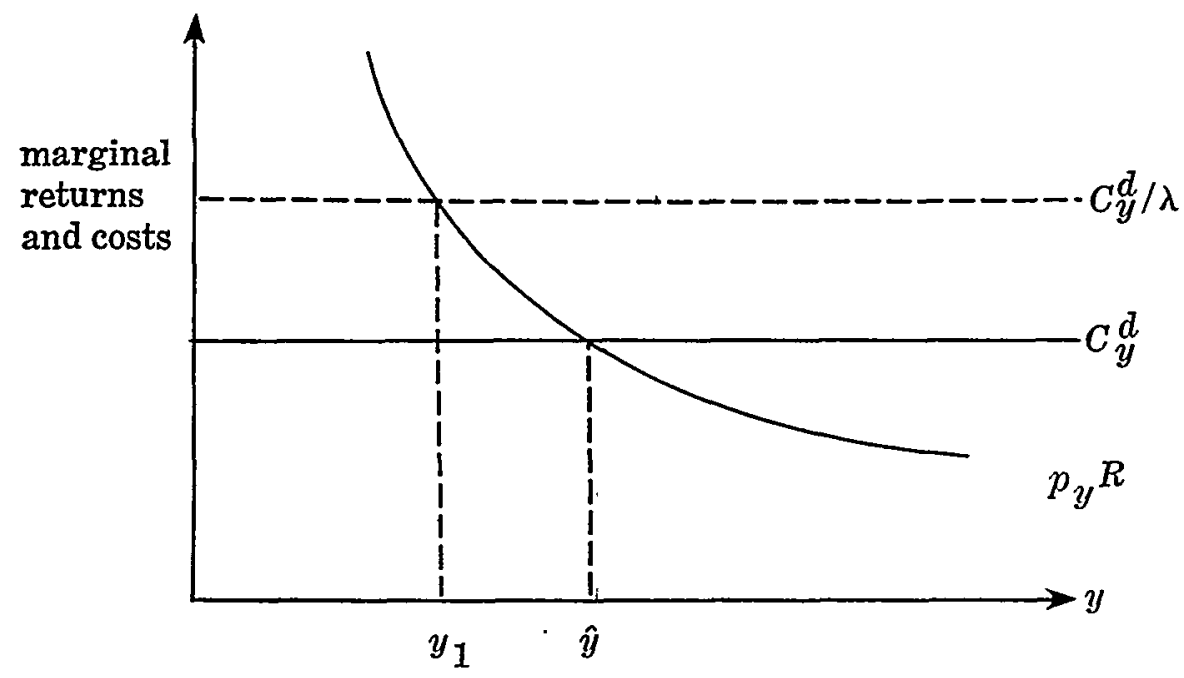

Now suppose that the indirect purchaser is also allowed to recover. The direct purchaser would still maximize his expected gain from enforcement, $\lambda p R-C^{d}\left(y^{d}\right)$, which yields

$$
p_{y} R-C \underset{y}{d} / \lambda=0
$$

But when $\lambda<1$, this is equivalent to an increase in the direct purchaser's marginal costs of enforcement, leading to a reduction in his inputs of $y$ from $\hat{y}$ to $y$ in Figure 3. In other words, a lower expected recovery will induce him to reduce his level of expenditure on antitrust enforcement. To illustrate, let $\lambda$ equal .5 and $C_{y}^{d}$ equal $\$ 1$. It follows that the direct purchaser will increase his enforcement inputs only up to the point at which $\$ 1$ in marginal costs generates $\$ 2$ in marginal returns, because he receives only 50 percent of those returns.

Although the direct purchaser has less incentive to spend on litigation, it might appear that this reduction would be offset by the creation of incentives for the indirect purchaser to spend. But, surprisingly, this is not the case. In fact, in the example given, the 
indirect purchaser has no incentive to add even a dollar in expenditure. ${ }^{44}$ At $y_{1}$ units of enforcement inputs in Figure 3 the marginal cost of an additional input to the indirect purchaser equals $\$ 1$, but aggregate marginal returns are slightly below $\$ 2$. Thus, from the indirect purchaser's viewpoint, a 50 percent share of these marginal returns is less than his dollar marginal cost. ${ }^{45}$

If we relax the assumptions that enforcement costs are identical and that $\lambda$ equals .5 , enforcement will be carried to the point at which

$$
p_{y} R-\min \left(C_{y}^{d} / \lambda, C_{y}^{i} /(1-\lambda)\right)=0
$$

where $\min (\cdot)$ denotes the minimum of either the direct or indirect purchaser's marginal costs adjusted upward by his respective share in the recovery. As equation (11) shows, when the parties have identical enforcement costs, the level of $y$ is lowest under an equalsharing rule. It also follows that if $C_{y}^{d}<C_{y}^{i}$, the level of enforcement is greatest when $\lambda=1$-which is the rule of Illinois Brick. ${ }^{46}$

The paradox of less enforcement with more potential enforcers is simply an application to antitrust enforcement of the well-known economic problem of external economies. Each party's expenditure on enforcement confers a benefit on the other parties, but no one has an incentive to take account of this external benefit in determining the level of his own expenditures. There are, to be sure, incentives to try to internalize the external benefits, thereby bringing the level of enforcement closer to the $\hat{y}$ level in Figure 3 . One possibility is

"He would, however, still have to spend the minimum amount necessary to maintain himself as a party to the suit. If these expenditures were counted as part of $y$, then $y$ would still not increase above $y_{1}$ in Figure 3 because the direct purchaser would cut back on his $y$ to maintain $y=y_{1}$.

${ }^{15}$ One can reverse the sequence (i.e., have the indirect purchaser initially spend $y_{1}$ and show that the direct purchaser will then choose to spend nothing) without altering the fundamental resui' that enforcement and hence deterrence of antitrust violations will fall with nonexclusive enforcement rights. The fact that the outcome does not depend on the sequence implies that though $y_{1}$ is the ultimate solution we do not know how the costs of $y_{1}$ will be allocated between the two parties.

${ }^{46}$ When $C$ is included as part of the recovery the general solution to $y$ is

$$
p_{y} R-\min \left(\frac{C_{y}^{d}(1-\mathrm{p}(1+\mathrm{e}))}{\lambda}, \frac{C_{y}^{i}(1-\mathrm{p}(1+\mathrm{e}))}{(1-\lambda)}\right)=0
$$

where $e$ is the percentage change in $p$ from a one percent change in $y$. This has the effect of lowering the plaintiff's marginal cost (since there is only a 1-p probability that he will bear these costs) and increasing the level of enforcement compared to the example in the text. Our result; however, that enforcement is maximized with exclusive rights assigned to the lowest cost enforcer (the direct purchaser) still holds. Note further that if the defendant's costs were assessed against the plaintiff when the prosecution was unsuccessful, this would of iset to a large extent the addition to recovery of the plaintiff's costs when the prosecution is successful. 
full cooperation and cost sharing. For example, if $\lambda=.5$ and the two parties cooperated fully, they might be able to agree to contribute $\$ .50$ each per unit of $y$ costing $\$ 1$. Full cooperation would push their joint expenditures on $y$ up to $\hat{y}$. Cooperation, however, is costly. Not only may the parties' interests conflict on certain issues (for example, the amount of passing on, which determines $\lambda$ ), but each party has an incentive to take a free ride on the others. The incentive to free ride is greater the greater the number of indirect purchasers.

Another possibility is for one party to obtain exclusive enforcement rights by buying the rights of the other party. Since these rights will tend to be worth more to the party whose costs of enforcement are lowest, the direct purchaser would be the one most likely to acquire exclusive rights via a market transaction with the indirect purchaser. Even if the courts enforce such contracts, however, there are difficulties in developing a market for the transfer of enforcement rights. ${ }^{47}$ First, there is a serious problem of holdouts, because indirect purchasers will have an incentive to seek to extract the full value of the expected gain from exclusive enforcement rights. Second, if the number of indirect purchasers is large and difficult to estimate, then the acquisition of rights from a group of indirect purchasers will not preclude others from later asserting their claim-possibly for the entire amount passed on to all indirect purchasers. In sum, our analysis suggests that with nonexclusive rights the parties will not be able to internalize fully the external benefits created by their enforcement efforts and therefore that less enforcement will result if Illinois Brick is overruled even if indirect purchasers are as efficient antitrust enforcers as direct purchasers.

\section{EMPIRICAL ANALYsis}

Although the theoretical case for believing that overruling Illinois Brick would actually reduce the deterrent efficacy of antitrust enforcement seems convincing to us, the question is ultimately an empirical one. Unfortunately, the Illinois Brick decision is so recent that its effect on antitrust enforcement cannot easily be gauged. Studies by Handler and by Kirkham, however, provide indirect evidence. ${ }^{48}$ They show that direct-purchaser suits are far more numerous than indirect-purchaser suits. This means, as a matter of

47 For a detailed analysis of the theoretical problems of exchanging enforcement rights see Landes \& Posner, supra note 15.

13 See note 30 supra. 
simple arithmetic, that if legislation overruling Illinois Brick had an equal but opposite effect on direct- and indirect-purchaser suits-decreasing the former, and increasing the latter, by the same number-the negative effect would outweigh the positive: the total number of suits would fall. The studies also show-what everyone knew-that there are an immense number of direct-purchaser suits and no evidence of bashfulness on the part of such purchasers about to sue.

The impact of Illinois Brick on the effectiveness of antitrust enforcement can, however, be studied in a more systematic fashion. Two approaches are possible. The first is to examine the effect of earlier antitrust decisions, mainly Hanover Shoe, ${ }^{49}$ which strengthened the incentives of direct purchasers to sue. Although our theoretical analysis stressed the probably adverse consequences on private enforcement of measures that weakened the incentives of direct purchasers, the converse also follows-strengthening the direct purchaser's incentives should increase the level of enforcement. Therefore, the Supreme Court's holding in Hanover Shoe (as well as similar holdings in lower courts prior to Hanover Shoe), ${ }^{50}$ which barred a defendant from arguing that the direct purchaser was not injured by the illegal overcharge because he had passed it on to indirect purchasers, should have substantially strengthened direct purchasers' incentives to uncover and prosecute violations. Thus we predict an increase, other things being equal, in private enforcement in the period following Hanover Shoe compared to the period before.

The second approach involves examining the effect of Illinois Brick on enforcement. Our analysis predicts that, other things being equal, Illinois Brick would increase the level of private enforcement.

19 See text and notes at notes 3-4 supra.

so Until 1964, the First, Fourth, Seventh, Eighth, and Ninth Circuits recognized the passing-on defense, Beacon Fruit \& Produce Co. v. H. Harris \& Co., 260 F.2d 958 (1st Cir. 1958) (per curiam) (dictum), cert. denied, 359 U.S. 984 (1959); Miller Motors, Inc. v. Ford Motor Co., 252 F.2d 441, 448 (4th Cir. 1958) (dictum); Northwestern Oil Co. v. SoconyVacuum Co., 138 F.2d 967 (7th Cir. 1943), cert. denied, 321 U.S. 792 (1944); Clark Oil Co. v. Phillips Petroleum Co., 148 F.2d 580 (8th Cir.), cert. denied, 326 U.S. 734 (1945); Wolfe v. National Lead Co., 225 F.2d 427 (9th Cir.), cert. denied, 350 U.S. 915 (1955), while the remaining circuits had either explicitly rejected passing on, Hanover Shoe, Inc. v. United Shoe Mach. Corp., 281 F.2d 481 (3d Cir.) (per curiam), cert. denied, 364 U.S. 901 (1960); Atlantic City Elec. Co. v. General Elec. Co., 226 F. Supp. 59 (S.D.N.Y. 1964), or had not been presented with the question. In 1964 the Seventh Circuit and the Western District of Washington, both of which had previously accepted the passing-on defense, rejected it, Commonwealth Edison Co. v. Allis-Chalmers Mfg. Co., 335 F.2d 203 (7th Cir. 1964); Public Util. Dist. No. 1 v. General Elec. Co., 230 F. Supp. 744 (W.D. Wash. 1964). Thus by the time Hanover Shoe was decided, only the First, Fourth, and Eighth Circuits recognized the passing-on defense. 
Moreover, since two circuits (the Third and Eighth) and three districts (New York Southern, Ohio Northern, and Colorado) had already adopted the rule of Illinois Brick prior to the Supreme Court's 1977 decision, ${ }^{51}$ we would predict that any increase in private enforcement after 1977 would take place primarily in those circuits and districts not having an Illinois Brick rule before 1977. A major difficulty with this analysis is that data are available for only a single year following the Illinois Brick decision, and hence are not a reliable indicator of the long-run effects of the decision.

To study the above questions, we used published data on private antitrust cases filed in the district courts. Because of the serious limitations of these data, our empirical analysis is highly tentative. We note at the outset two serious data problems that probably could be overcome by additional work, and a third that probably could not be.

First, annual published data on private antitrust cases are of cases commenced (that is, filed). If, for example, five plaintiffs commence a suit against a defendant (or group of defendants) for the identical violation, this may be recorded as five separate cases. Yet for our purposes it should count as a single suit because we are interested only in the enforcement of the antitrust laws against the defendant. This factor creates a bias against finding a positive effect on enforcement of Illinois Brick because the typical case involving indirect purchasers will tend to have more plaintiffs and thus more filings.

Second, the published data on private antitrust suits pertain to all types of antitrust cases. Many cases involve no charges of price fixing, and hence no direct and indirect purchasers, but instead are brought by competitors or franchisees. Thus, data on total private cases may be a poor approximation for the number of suits brought by direct and indirect purchasers for an illegal overcharge. For example, yearly variations in the number of antitrust suits brought by competitors would generate variations in cases commenced in a district that are unrelated to the direct- or indirect-purchaser issue.

Third, the number of case filings is a poor proxy for the effectiveness of antitrust enforcement, in the same way that the number of nuclear wars is a poor proxy for the effectiveness of the nuclear

31 Our sources are Illinois v. Ampress Brick Co., 67 F.R.D. 461, 464 n.1 (N.D. Ill. 1975), rev'd on other grounds, 536 F.2d 1163 (7th Cir. 1976), rev'd sub. nom. Illinois Brick Co. v. Illinois, 431 U.S. 720 (1977), and S. REP. No. 934, 95th Cong., 2d Sess. 10-11 (1978). These sources are not entirely consistent, and we have had to exercise judgment in classifying states on the basis of their pre-Illinois Brick position on indirect-purchaser suits. 
deterrent. If the rule of Illinois Brick is more effective in deterring antitrust violations than a rule under which indirect purchasers are permitted to sue, one might observe a drop in the number of cases filed that could be completely consistent with the conclusion that Illinois Brick had increased the effectiveness of private antitrust enforcement.

Subject to these qualifications, we have attempted to determine the effect of Hanover Shoe and Illinois Brick on the number of private antitrust cases filed. Table 1 traces the change in the annual number of private antitrust cases filed since 1960 . Columns 2 and 3 attempt to isolate the effects due to Hanover Shoe and Illinois Brick from other factors affecting change in the number of private antitrust cases. Part of the growth in private antitrust cases may be due to a general growth over time in litigation. Column 2 attempts to net out this factor by examining the growth of private antitrust cases relative to that of all private civil cases in the federal courts. Other possible factors in the growth of private antitrust cases are increasing numbers of antitrust violations and changes in the number of government antitrust suits (since private plaintiffs can often take a "free ride" on the government's case). Column 3 attempts to correct for these factors by relating the number of private cases to the number of government cases filed.

\section{A. The Effect of Hanover Shoe}

After these corrections are made it is still evident that the number of private antitrust suits has been increasing rapidly. Conceivably the strengthening of the direct purchaser's incentives to sue brought about by the Hanover Shoe decision in 1968 is a factor in the growth of private antitrust suits. Table 1 shows that the ratio of private antitrust suits to all private civil cases averaged .0159 in the 1960 to 1968 period but rose to .0202 in the 1969 to 1978 period. Thus, the share of private antitrust suits increased by about 27 percent in the post-Hanover Shoe period. ${ }^{52}$ Similarly, the ratio of government civil to private antitrust cases fell from an average of .0722 to .0414 between the pre- and post-Hanover Shoe periods. ${ }^{53}$

32 If we exclude the electrical machinery cases the difference between the pre- and postHanover Shoe period is even more marked-a more than 100 percent increase from .1197 to .0202 .

${ }_{53}$ A factor that militates against attributing all of the differences between the pre- and post-Hanover Shoe period to the impact of that decision is the more or less continuous growth in private antitrust cases dating back to 1960 . 
Table 1

Private Antitrust Cases Commenced

in U.S. District Courts, 1960-1978

\begin{tabular}{|c|c|c|c|}
\hline Year & $\begin{array}{l}\text { Priv. } \\
\text { Antitrust } \\
\text { Cases a } \\
\text { (1) }\end{array}$ & $\begin{array}{l}\text { Ratio of Priv. } \\
\text { Antitrust to } \\
\text { Private Civil } \\
\text { Cases b } \\
\text { (2) }\end{array}$ & $\begin{array}{l}\text { Ratio of } \\
\text { Gov't Antitrust } \\
\text { to Private } \\
\text { Antitrust } \\
\text { Cases c } \\
\text { (3) }\end{array}$ \\
\hline 1960 & 228 & .0061 & .2632 \\
\hline 1961 & 378 & .0101 & .1111 \\
\hline 1962 & 2005 & .0500 & .0204 \\
\hline 1963 & 380 & .0096 & .1368 \\
\hline 1964 & 363 & .0090 & .1652 \\
\hline 1965 & 472 & .0116 & .0805 \\
\hline 1966 & 722 & .0174 & .0499 \\
\hline 1967 & 543 & .0131 & .0718 \\
\hline 1968 & 659 & .0152 & $.0728^{\circ}$ \\
\hline 1969 & 740 & .0162 & .0581 \\
\hline 1970 & 877 & .0174 & .0593 \\
\hline 1971 & 1445 & .0257 & .0415 \\
\hline 1972 & 1299 & .0227 & .0616 \\
\hline 1973 & 1152 & .0197 & .0469 \\
\hline 1974 & 1230 & .0197 & .0325 \\
\hline 1975 & 1375 & .0193 & .0407 \\
\hline 1976 & 1504 & .0199 & .0339 \\
\hline 1977 & 1611 & .0213 & .0292 \\
\hline 1978 & 1435 & .0191 & .0293 \\
\hline \multicolumn{4}{|l|}{$1960-$} \\
\hline 1968 & 5750 & .0159 & .0722 \\
\hline \multicolumn{4}{|l|}{1969} \\
\hline 1978 & 12668 & .0202 & .0414 \\
\hline
\end{tabular}

SOURCE: data derived from Tables 27 and 28, [1978] ADMIN. OfFICE of The U.S. CourTs ANN. REP. 77, 78.

a Includes electrical industry cases ( 37 in 1961, 1739 in 1962, 97 in 1963, 46 in 1964, 29 in 1965, 278 in 1966, and 7 in 1967).

b Private civil cases exclude prisoner petitions.

c Government antitrust cases are civil only and include 9 electrical machinery cases in 1961, 2 in 1962 and 3 in 1963.

Multiple regression analysis provides a more systematic method of analyzing the time trend of private antitrust cases because it enables us to separate the effects on this variable of the overall growth in private federal-court litigation and in government antitrust activity from the effect of the Hanover Shoe decision. The following variables were used in the regression analysis: 
Y: annual private antitrust cases commenced in the U.S. district courts

GOVT: annual government antitrust cases (civil. only) commenced in the U.S. district courts

CIV: annual private civil cases (excluding antitrust) commenced in the U.S. district courts

RATIO: the ratio of $Y$ to $C I V$

TIME: time trend $(1=1963,2=1964$, etc. $)$

$H A N$ : proportion of circuits and districts per year that allowed the passing-on defense. ${ }^{54}$

Table 2 presents the results of our multiple regression analysis. Each regression equation is estimated from annual data from 1963 to 1977 and therefore contains 15 observations. ${ }^{55}$ In all equations the $H A N$ variable is statistically significant (at the .05 level or greater) and has the predicted sign. That is, allowing the passing-on defense to be raised is associated with a significant reduction in the number of private antitrust cases; alternatively, disallowing the defense significantly increases the number of antitrust cases. Specifically, our regression analysis indicates that the Hanover Shoe decision is associated with a 26 to 35 percent increase (equations 2-1 and 2-2 respectively) in private antitrust cases commenced per year, holding constant the overall time trend in civil litigation and the number of government antitrust cases. ${ }^{56}$ Similarly, equation $2-3$ indicates that the ratio of private antitrust cases to private civil litigation (excluding antitrust) increased by about 33 percent in response to the Hanover Shoe decision.

54 This proportion was calculated as follows. For each year prior to Hanover Shoe we first determined the circuits and districts that allowed the passing-on defense. See note 50 supra. We then computed the proportion of private civil cases (excluding antitrust) in all district courts commenced in the districts that allowed the passing-on defense. The proportions were .299 in 1963, .313 in 1964, .158 in 1965, .161 in 1966, .163 in 1967, and .162 in 1968, and 0 after 1968. In estimating the impact of Hanover Shoe, or more generally of rejecting the passing-on defense, the HAN variable enables us to take account of the reduction in the number of districts, appropriately weighted to reflect their relative numerical importance in federal cases, that permitted the passing-on defense prior to the Hanover Shoe decision.

${ }_{55}$ The analysis was limited to these years for several reasons. First, we were not confident of our ability to classify circuits and districts into those that permitted passing on prior to 1963 and those that did not. Second, the extraordinary total number of cases in 1962 (see Table 1) due to the electrical machinery litigation suggests that this year should probably be excluded from a time-series study. Finally, we excluded 1978 in order not to confound our analysis with the impact of Illinois Brick.

ss Since the proportion of districts permitting a passing-on defense was .162 in 1968 and Hanover Shoe reduced this proportion to zero, the percentage change in private antitrust cases associated with Hanover Shoe would equal (1.582)(.162)(100) and (2.187)(.162)(100) in equations $2-1$ and $2-2$, respectively. 
Table 2

Regression Analysis of Private

Antitrust Cases, 1963-1977

(t-statistics in parentheses)

Equa-Depend-

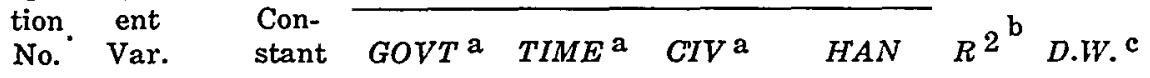

Independent Variables

$\begin{array}{ccccccccc}2-1 & Y & 5.482 & .214 & .071 & - & -1.582 & .94 & 2.33 \\ & & (7.42) & (1.10) & (4.00) & & (2.32) & & \\ 2-2 & Y & 2.053 & .114 & - & 1.123 & -2.187 & .94 & 2.27 \\ & & (1.75) & (.58) & & (4.09) & (4.00) & & \\ 2-3 & R A T I O & 4.499 & .124 & .010 & - & -2.039 & .82 & 2.25 \\ & & (6.08) & (.65) & (.58) & & (3.06) & & \end{array}$

SOURCE: data derived from [1963-1977] ADMINISTRATIVE OFFICE OF THE U.S. COURTS ANN. ReP.

a, GOVT and $C I V$ are in natural logarithms.

${ }^{b} R^{2}$ is the coefficient of determination.

c $D . W$. is the Durbin-Watson statistic.

Although the impact of Hanover Shoe might appear to be unusually large in view of the small proportion of the districts that accepted the passing-on defense prior to Hanover Shoe, that decision would also have had effects both in districts that had not yet ruled on the passing-on question and in those that had explicitly rejected the passing-on defense prior to 1968. In the former, Hanover Shoe would have removed the uncertainty surrounding the legality of the passing-on defense and thus increased the incentives of direct purchasers to bring suits. In the latter, some direct purchasers may have decided against bringing marginal private suits because of the possibility of the Supreme Court's upholding the passing-on defense in Hanover Shoe. ${ }^{57}$

${ }^{57}$ Overall, the regression equations in Table 2 explain a substantial share of the variation (between 82 and 94 percent) of private antitrust cases in the 1963 to 1977 period. The TIME variable in equation 2-1 indicates a 7 percent annual increase in private antitrust cases during the 1963 to 1977 period whereas the $C I V$ variable in 2-2 indicates that private antitrust cases grew 12 percent more rapidly than did private civil litigation in general (e.g., a 5 percent annual growth in civil litigation is associated with a 5.6 percent annual growth in private antitrust cases). We also estimated an equation (not presented in Table 2) that included both the TIME and $\log C I V$ variables. Since the correlation between TIME and $\log C I V$ is .97 , neither coefficient was significant in this regression. The coefficient on $H A N$, however, continued to have a negative and significant effect. The GOVT variable in Table 2, though suggesting a positive relation between private and government cases, is not statistically significant in any of the regressions. Similarly, the TIME variable in the RATIO equation indicates the absence of a significant trend in the ratio of antitrust to other civil cases. 


\section{B. The Effect of Illinois Brick.}

The foregoing analysis provides support for our theoretical conclusion that Hanover Shoe would strengthen antitrust enforcement by increasing the direct purchaser's incentive to sue. But our effort to determine the effect on antitrust enforcement of Illinois Brick itself was much less successful. A serious problem is that post-Illinois Brick data are available for only one year (fiscal 1978), and a single year's experience is too limited to support confident inferences regarding the effect of Illinois Brick. This caveat should be borne in mind in interpreting the empirical analysis that follows.

Table I shows that private antitrust cases fell by 10.9 percent (column 1) between fiscal 1977 and fiscal 1978-10.3 percent relative to all private civil cases (column 2). But before drawing any firm conclusions regarding the impact of Illinois Brick, one should note that these reductions are no greater than some that occurred in earlier years. For example, private antitrust cases dropped by 10.3 percent from 1971 to 1972 and by 11.3 percent from 1972 to 1973. There are similar declines of 11.7 and 12.3 percent in these two years for the ratio of private antitrust cases to all private civil cases (column 2).

Table 3 divides the district courts into three classes: those that barred indirect-purchaser suits prior to the Supreme Court's decision in Illinois Brick (column 1); those that permitted them (column 2 ); and those in which the standing of indirect purchasers was undecided (column 3 ). ${ }^{58}$ The table indicates that the decline in the number of private antitrust cases filed in 1978 compared to the number filed the year before was concentrated in districts where indirectpurchaser suits had been allowed prior to Illinois Brick. Although this result is contrary to our theoretical argument that Illinois Brick strengthened antitrust enforcement (as well as our empirical findings concerning the impact of Hanover Shoe), the statistics actually provide little evidence that Illinois Brick has reduced the amount of private activity. The further breakdown of Table 3 in the indirectpurchaser districts shows that four districts (columns 4 to 7 ) account for virtually all of the drop in private antitrust cases even though the four account for only 36 percent of the private antitrust cases filed in the indirect-purchaser districts. And an analysis of the annual variations in the four districts suggests that the sharp drop from 1977 to 1978 was probably unrelated to Illinois Brick.

Finally, the Durbin-Watson statistics indicate no serious first-order autocorrelation problems in the residuals.

${ }^{58}$ Inevitably, some subjective judgment entered into this classification of districts. See 
Table 3

Private Antitrust Cases

in District Courts 1969-1978

Classified by Direct and Indirect

Purchaser Rule

In-

direct

Pur-

Direct chaser

Pur- Per-

chaser mitted

Only to Sue

(1)

(2)

Un-
clear

(3)
Indirect

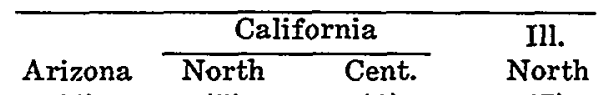

(4)

(5)

(6)

(7)

\begin{tabular}{rrrrrrrr}
\hline 1969 & 241 & 360 & 139 & 14 & 100 & 48 & 88 \\
1970 & 317 & 417 & 143 & 20 & 90 & 48 & 81 \\
1971 & 628 & 624 & 193 & 15 & 184 & 104 & 86 \\
1972 & 389 & 655 & 255 & 11 & 150 & 98 & 101 \\
1973 & 355 & 544 & 253 & 14 & 81 & 82 & 95 \\
1974 & 316 & 615 & 299 & 22 & 76 & 78 & 65 \\
1975 & 399 & 643 & 333 & 20 & 94 & 78 & 78 \\
1976 & 429 & 756 & 319 & 19 & 164 & 88 & 96 \\
1977 & 419 & 850 & 342 & 42 & 110 & 89 & 137 \\
1978 & 404 & 691 & 340 & 22 & 71 & 69 & 87
\end{tabular}

SOURCE: data derived from [1968-1978] ADMIN. OFFICE of THE U.S. CoURTS ANN. REP. and sources cited in note 51 supra.

District of Arizona. Although the number of cases dropped by 20 from 1977 to 1978, this decline may have been due not to Illinois Brick but to the fact that the number of cases filed in 1977 was far greater than in any previous year. The 42 cases filed in 1977 is an outlying observation relative to the norm of the prior three years (19 to 22 cases) and thus the drop from 42 to 22 after Illinois Brick may be simply a return to the normal trend. To attribute the 1977 to 1978 change to Illinois Brick, one would first have to explain the dramatic increase from 1976 to 1977 and show that it was not a transitory increase but somehow represented a permanent shift to a higher level of enforcement in Arizona.

Northern District of California. Here we observe a reduction in 39 cases between 1977 and 1978, but, inexplicably, we also observe an even larger reduction of 54 cases between 1976 and 1977. Moreover, there was a still larger drop of 69 cases between 1972 and 1973. It is misleading to attribute the decline from 1977 to 1978 to Illinois Brick when even larger declines occurred in two of five years prior to Illinois Brick.

Central District of California. The decline of 20 cases between 1977 and 1978 may be the result of Illinois Brick, but, again, there 
was a drop of similar magnitude between 1972 and 1973.

Northern District of Illinois. The 70-case reduction between 1977 and 1978 may simply be the result of the abnormally sharp increase in cases in 1977 (and possibly 1976). Again, unless there is some reason to believe that the 1977 figure represented a permanent increase in the level of antitrust enforcement, it would be incorrect to attribute the subsequent decline to Illinois Brick.

\section{CONCLUSION}

Our analysis has suggested that the rule of Illinois Brick, which bars indirect purchasers from bringing private antitrust damage actions, is probably the soundest rule from the standpoint of maximizing the effectiveness of antitrust enforcement. We anticipate the argument that, however abstractly desirable it may seem to confine enforcement to direct purchasers, to do so is to alter the fundamental character of the private antitrust action in a way that cannot be squared with the intent of Congress in creating private damage remedies for antitrust violations. One way of characterizing our position is that it allows someone who may not be injured (or not injured much) - the direct purchaser-to recover (treble) damages while denying the right to recover any damages to other people-indirect purchasers-who may in fact be injured. There is an element of paradox in this result, but it is dispelled by careful analysis. As we have shown, even if indirect purchasers were given the nominal right to sue, they would often fail to receive significant compensation. And anyone troubled by the windfall element in the judgment received by the direct purchaser must in logic reexamine the entire structure of private antitrust enforcement. Two-thirds of every private antitrust damage judgment (the punitive component of the judgment) is a windfall to the purchaser.$^{59}$ In a class action, much of even the compensatory portion of the judgment may end up in the pockets of lawyers or in state treasuries, rather than in the pockets of the people who were actually harmed by the antitrust violation. The windfall element cannot be purged from the private antitrust suit without a complete reworking of antitrust enforcement. Until that is done, society will be well-advised to allow some direct purchasers to enjoy windfalls if, as we have argued, the direct-

59 This is something of an exaggeration since the "punitive" component can be viewed in part (but only in part) as simply covering items of real damage, such as interest, that the legal computation of compensatory damages excludes. 
purchaser suit is on balance a more effective instrument for enforcing the antitrust rule prohibiting price fixing than the indirectpurchaser suit. 